\title{
Yield and Essential Oil Composition of Thymus eigii (M. Zohary \& P.H. Davis) Jalas Leaves and Flowers at Various Growth Stages in the Mediterranean Region
}

\author{
Muzaffer Barut ${ }^{*}$, Leyla Sezen Tansi², Şengül Karaman ${ }^{3}$ \\ 1* Çukurova University, Faculty of Agriculture, Departmant of Field Crops, Adana, Turkey, (ORCID: 0000-0002-9095-8225), \\ muzafferbarut1@gmail.com \\ ${ }^{2}$ Çukurova University, Faculty of Agriculture, Departmant of Field Crops, Adana, Turkey, (ORCID: 0000-0003-0726-3332), \\ 1sezen@cu.edu.tr \\ ${ }^{3}$ Kahramanmaras Sutcu Imam University, Faculty of Science and Letter, Departmant of Biology, Kahramanmaraş, Turkey, (ORCID: 0000-0001-7617-9957), \\ sengulk@ksu.edu.tr
}

(First received 15 October 2021 and in final form 16 December 2021)

(DOI: 10.31590/ejosat.1010281)

ATIF/REFERENCE: Barut, M., Tansı L.S., Karaman, Ş., (2021). Yield and Essential Oil Composition of Thymus eigii (M. Zohary \& P.H. Davis) Jalas Leaves and Flowers at Various Growth Stages in the Mediterranean Region. European Journal of Science and Technology, (31), 523-530.

\begin{abstract}
Thymus eigii is a perennial shrub from Lamiaceae family and it is found as wild in Adana and Hatay provinces, Turkey. The potential use of Thymus spp. in the prevention of viral diseases is making its demand rise. In this study, T. eigii plants were collected at various growth stages (pre-flowering, mid-flowering, and full-flowering) from Adana, Turkey in order to determine the most suitable harvest time for the highest amount of essential oil and yield. Full-flowering resulted in the highest plant height $(36.11 \mathrm{~cm})$, plant diameter $(57.30 \mathrm{~cm})$, fresh herb yield $\left(251.31 \mathrm{~g} \mathrm{plant}^{-1}\right)$, fresh flower yield $\left(158.24 \mathrm{~g} \mathrm{plant}^{-1}\right)$, dry herb yield $\left(84.73 \mathrm{~g} \mathrm{plant}^{-1}\right)$, and dry flowers yield $\left(53.63 \mathrm{~g} \mathrm{plant}^{-1}\right)$, whereas the highest fresh leaves yield $\left(38.97 \mathrm{~g}\right.$ plant $\left.^{-1}\right)$ and dry leaves yield $\left(16.72 \mathrm{~g} \mathrm{plant}^{-1}\right)$ were found at mid-flowering. While the highest flower essential oil rate $\left(4.75 \mathrm{ml} 100 \mathrm{~g}^{-1}\right)$ was obtained at mid-flowering, the highest leaves essential oil rate $\left(2.77 \mathrm{ml} 100 \mathrm{~g}^{-1}\right)$ was found at pre-flowering. The major compounds were carvacrol (70.87-77.98\%), p-Cymene (3.39-7.46\%), $\beta$-Caryophyllene (3.90-5.17\%), $\gamma$-Terpinene (0.58-5.15\%), and isoborneol $(0.30-3.58 \%)$. As a result, the most suitable harvest time was determined as pre-flowering in terms of dry leaf yield and full-flowering in terms of flowers essential oil yield.
\end{abstract}

Keywords: Thymus, Essential oil, Carvacrol, Wild species.

\section{Akdeniz Bölgesinde Thymus eigii (M. Zohary \& P.H. Davis) Jalas Bitkisinin Farklı Gelişme Devrelerinde Verimi ile Yaprak ve Çiçeklerdeki Uçucu Yağ Bileşimi}

$\ddot{\mathbf{O} z}$

Thymus eigii, Lamiaceae familyasından çok yıllık bir çalı olup, Türkiye'nin Adana ve Hatay illerinde yabani olarak bulunmaktadır. Thymus spp. türlerinin viral hastalıkların önlenmesi konusundaki potansiyel kullanımı talebi artırmaktadır. Bu çalışmada, en yüksek miktarda verim ve uçucu yăg elde etmek için en uygun hasat zamanını belirlemek amacıyla, Adana, Türkiye'den farklı çiçeklenme dönemlerinde (çiçeklenme öncesi, yarı çiçeklenme ve tam çiçeklenme) toplanmıştır. Tam çiçeklenmede en yüksek bitki boyu (36.11 $\mathrm{cm})$, bitki çapı $(57.30 \mathrm{~cm})$, taze bitki verimi $\left(251.31 \mathrm{~g}\right.$ bitki $\left.^{-1}\right)$, taze çiçek verimi $\left(158.24 \mathrm{~g} \mathrm{bitki}^{-1}\right)$, kuru bitki verimi $\left(84.73 \mathrm{~g}\right.$ bitki $\left.{ }^{-1}\right)$, kuru çiçek verimi (53.63 $\left.\mathrm{g} \mathrm{bitki}^{-1}\right)$ saptanırken, en yüksek taze yaprak verimi (38.97 $\left.\mathrm{g} \mathrm{bitki}^{-1}\right)$ ve kuru yaprak verimi (16.72 $\mathrm{g}$ bitki $\left.{ }^{-1}\right)$ ise yarı çiçeklenmede belirlenmiştir. En yüksek çiçek uçucu yağ oranı $\left(4.75 \mathrm{ml} 100 \mathrm{~g}^{-1}\right)$ yarı çiçeklenmede, en yüksek yaprak uçucu yağ oranı $\left(2.77 \mathrm{ml} 100 \mathrm{~g}^{-1}\right)$ ise çiçeklenme öncesi dönemde bulunmuştur. Başlıca bileşikler karvakrol (\% 70.87-77.98), p-Cymene (\%3.39-7.46), $\beta$-Caryophyllene (\%3.90-5.17), $\gamma$-Terpinen (\%0.58-5.15) ve izoborneol (\%0.30-3.58) olarak saptanmıştır. Sonuç olarak en uygun hasat zamanı kuru yaprak verimi açısından çiçeklenme öncesi, çiçek uçucu yağ verimi açısından ise tam çiçeklenme olduğu belirlenmiştir.

Anahtar Kelimeler: Thymus, Uçucu yağ, Karvakrol, Yabani türler.

*Corresponding Author: muzafferbarut1@gmail.com 


\section{Introduction}

Thymus eigii (syn. T. syriacus subsp. eigii) (Lamiaceae) is native to southern Europe and Asia and it is a member of the Thymus genus, which contains approximately 300 species of hardy perennial herbaceous plants and subshrubs (Könemann, 1999). T. eigii is called "kekik" like other Thymus, Coriandrum, Thymbra, Coridothymus, and Satureja species available in the Turkish flora, and this plant is narrowly distributed in southern Anatolia (Davis, 1982; Ozguven ve Tansi, 1998, Kocabas ve Karaman, 2001). It grows as wild at 500-915 m in Lebanon, Syria, and Turkey (TUBIVES, 2021).

Thymus oil, along with essential oils of clove, lemon, and chamomile, was used as a disinfectant and antiseptic in hospitals until the early 20th century (Ryman, 1992). There have been several reports in the literature on the antibacterial and antioxidant activities of various Thymus species, and essential oils have frequently stayed at the heart of many studies (Baydar, 2016). This genus is also well-known for a variety of additional pharmacological characteristics, including spasmolytic, expectorant, and mammalian age delaying effects (Stahl-Biskup, 1991; Rasooli and Mirmostafa, 2002). Moreover, the essential oils of several Thymus species are widely utilized as flavoring agents in food processing, and thyme oil is still ranked among the top ten essential oils in the world (Stahl-Biskup, 1991). Herba is mainly used in meat dishes, vegetable dishes, various sauces and salads, cheese and sausage production. Thymus spp. is a good pollen source for bees and a high-quality herbal source for dairy animals. Therefore, the honey of the bees fed with Thymus spp. and the dairy products of the animals grazed with thyme are of high quality (Ortiz ve Fernandez, 1992).

The status of Mediterranean cuisine and the health benefits of Thymus spp. are contributing to the rising demand in the European market. Germany is Europe's main importer of dried leaves of Thymus spp. with special deals for organic suppliers. Besides Germany, other significant and developing markets with potential for new emerging nation suppliers include Spain, Belgium, the United Kingdom, France, and the Netherlands (Eurostat, 2021). Poland is the biggest EU producer, followed by Spain and France, however, large volumes are imported from non-European countries. Morocco, Egypt, Turkey, Israel, Syria, and Albania are major suppliers (Eurostat, 2021).

The flora of Turkey, which is very rich in medicinal and aromatic plants and endemic plants, has been destroyed due to unconscious collections, destruction of nature, and environmental pollution, and many species are in danger of extinction. Thymus spp. also gets its share from them (Ozguven ve Tans1, 1998). Two of the most significant strategies for biological variety conservation are germplasm collection and ex situ conservation in gene banks. Several Thymus species are of particular importance as wild relatives of plants, with the goal of utilizing them to improve through plant breeding. All across the world, 684 Thymus accessions are present and Thymus vulgaris shares 19\% and Thymus serpyllum 14\%, Thymus pulegioides $\% 13$, Thymus mastichina \%5, Thymus praecox $4 \%$ of these accessions, respectively. Research Station of Medicinal Crops, Ukraine (UKR019) conserves the world's largest and most diverse collection of Thymus (Genesys, 2021).

Medicinal and aromatic plants have a very wide range of uses and their importance and therapeutic properties are usually characterized by their active ingredients. Plants' leaves, flowers, seeds, and fruits are widely used as medicines, and the active ingredients of various plant parts fluctuate with growth seasons as well as changes in daily temperature and light intensity. Thus, a drug manufacturer should be well-versed in the variations of active ingredients and should harvest plants at the appropriate locations and the development stages when the plants were rich in drug-related active ingredients. Taking such alterations into account, the most accessible organ, development stage, and harvest time for drug acquisition can be determined. To the extent of our knowledge, there are no published studies investigating the effect of the different growth stages and organs on the quality and yield of T. eigii. Therefore, this study aimed to assess the ontogenetic and morphogenetic variability on yield and quality characteristics of $T$. eigii by comparing with various growth stages and organs in the Mediterranean region where the effects of global warming and climate change are intensively felt.

\section{Material and Method}

\subsection{Plant Material}

The area where Thymus eigii (M. Zohary \& P.H. Davis) Jalas species naturally spread were determined in the flora of Çürüklü, Kozan/Adana (37³9'23.6"N 3557'04.1"E). The slope is rocky-scree covered with Elymus sp., Echinops orientalis, Taraxcum officinale, Genista albida. The plants were identified according to the identification keys of Davis (1982) by the taxonomist Prof. Dr. Ahmet İlçim. The plants were collected in June-July 2021 at various growth stages (pre-flowering, midflowering, and full-flowering).

\subsection{Essential oil extraction}

$25 \mathrm{~g}$ dried leaves and dried flower samples from each treatment were weighed and placed in a glass balloon with 250 $\mathrm{ml}$ distilled water then placed in the Clevenger apparatus for essential oil hydrodistillation for 2 hours. The value was recorded (in $\mathrm{mL}$ ) from the apparatus. Essential oil stored at $4{ }^{\circ} \mathrm{C}$ until analyzed. The oil rate was stated on a dry tissue weight basis.

\subsection{Essential oil extraction}

GC-MS analyses were conducted in the Department of Biology at Kahramanmaras Sutcu Imam University. $10 \mu \mathrm{l}$ essential oil was mixed with $0.25 \mathrm{ml}$ dichloromethane and $1 \mu \mathrm{l}$ mixture was injected into the column. Essential oil compounds were detected using an Agilent 5975C mass spectrometer in conjunction with the Agilent GC-6890 II series. The GC was equipped with an HP-88 capillary column (100 m x $250 \mu \mathrm{m} \times$ $0.20 \mu \mathrm{m}$ film thickness) and the carrier gas flow rate was 1.0 $\mathrm{ml} / \mathrm{min}$. The oven temperature was held at $70{ }^{\circ} \mathrm{C}$ for $1 \mathrm{~min}$ and then increased from 70 to $220{ }^{\circ} \mathrm{C}$ at a rate of $10{ }^{\circ} \mathrm{C} / \mathrm{min}$ and waited for $10 \mathrm{~min}$. Then increased to $230{ }^{\circ} \mathrm{C}$ at a rate of 10 ${ }^{\circ} \mathrm{C} / \mathrm{min}$ and held at $10 \mathrm{~min}$. The temperature of the injection part was $250{ }^{\circ} \mathrm{C}$. The mass spectrometer was operated in EI mode at $70 \mathrm{eV}$. The split ratio was 20:1. Mass range $35-400 \mathrm{~m} / \mathrm{z}$; scan speed (amu/s): 1000. The compounds were identified by mass spectra using Flavor2, W10N14 and Wiley7Nist05 libraries as reference compounds. 


\subsection{Statistical analysis}

Morphological analyzes were performed on 30 plants and chemical analyzes were performed in triplicate. The experimental data regarding the results of morphological and chemical analysis were statistically analyzed by analysis of variance (ANOVA). Significantly different means were separated at $\mathrm{P}=0.05$ using the LSD (Least Significant Difference) test. ANOVA and principal components analysis on correlations were performed using statistical software JMP ${ }^{\circledR}$ (version 14.0, SAS Institute Inc., Cary, NC, 1989-2019). The heat map was constructed using Flourish studio.

\section{Results and Discussion}

\subsection{Morphological Traits}

To understand the effects of different growth stages some morphological traits were recorded and given in Table 1. Compared to the growth stages of T. eigii, full-flowering (36.11 $\mathrm{cm})$ and mid-flowering $(35.24 \mathrm{~cm})$ resulted in the highest plant height which was 12 and 9 percent higher than pre-flowering stages, respectively. The reduction in plant height with early growth stages could result from a shorter period of vegetative growth of plants. The plant height values for $T$. eigii are in harmony with the findings obtained by Ozguven and Kirici (2002). As in plant height, full-flowering $(57.30 \mathrm{~cm})$ and midflowering $(55.67 \mathrm{~cm})$ resulted in the highest plant diameter which was 25 and 22 percent higher than pre-flowering, respectively.

Full-flowering resulted in the highest fresh herb yield (251.31 g plant $^{-1}$ ) which was 20 and 43 percent higher than growth stages of mid-flowering and pre-flowering, respectively. Mid-flowering resulted in the highest fresh leaves yield $(38.97 \mathrm{~g}$ plant $^{-1}$ ) which was 17 and 43 percent higher than growth stages of pre-flowering and full-flowering, respectively. Full-flowering resulted in the highest fresh flower yield (158.24 $\left.\mathrm{g} \mathrm{plant}^{-1}\right)$ which was 30 percent higher than growth stages of mid-flowering. With the flowering, the plant ages and enters the generative phase and the large spring leaves fall in the summer and start to form small hard leaves that are resistant to heat. Therefore, very few leaves are obtained during the full flowering period.

Full-flowering resulted in the highest dry herb yield (84.73 g plant $^{-1}$ ) which was 26 and 55 percent higher than growth stages of mid-flowering and pre-flowering, respectively. Mid-flowering resulted in the highest dry leaves yield (16.72 $\left.\mathrm{g} \mathrm{plant}^{-1}\right)$ which was 17 and 32 percent higher than growth stages of preflowering and full-flowering, respectively. Full-flowering resulted in the highest dry flowers yield (53.63 $\left.\mathrm{g} \mathrm{plant}^{-1}\right)$ which was 42 percent higher than growth stages of mid-flowering.

Plants in different stages of development produce a strongly fluctuating content of essential oils. Pre-flowering resulted in the highest leaves essential oil rate $\left(2.77 \mathrm{ml}_{\left.100 \mathrm{~g}^{-1}\right)}\right.$ which was 14 and 66 percent higher than growth stages of mid-flowering and full-flowering, respectively. Mid-flowering resulted in the highest flower essential oil rate $\left(4.75 \mathrm{ml} 100 \mathrm{~g}^{-1}\right)$ which was 3 percent higher than the growth stage of full-flowering. When we compared these essential oil rate findings with the earlier studies, our results were found higher than their results; $1.84 \mathrm{ml}$

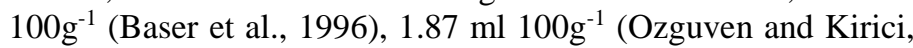

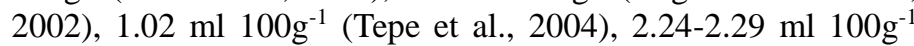
(Ozguven and Sekeroglu, 2008), 0.03-072 (Azaz et al., 2010), 1.04 (Ulukanli et al., 2018). Mid-flowering resulted in the highest leaves essential oil yield $\left(0.41 \mathrm{ml} \mathrm{plant}^{-1}\right)$ which was 3 and 95 percent higher than the growth stage of full-flowering and pre-flowering, respectively. Full-flowering resulted in the highest flowers essential oil yield $\left(2.47 \mathrm{ml} \mathrm{plant}^{-1}\right)$ which was 38 percent higher than the growth stage of mid-flowering, respectively. However, to the best of our knowledge, the essential oil rate of leaves and flowers were separately examined for the first time. It is believed that these different results are due to plant material, morphogenetic, and ontogenetic variability, as well as different collection areas due to ecological conditions.

Table 1. Morphological traits of Thymus eigii at various growth stages

\begin{tabular}{|c|c|c|c|c|c|c|c|}
\hline Morphological traits & Pre-flowering & Mid-flowering & Full-flowering & Mean & $\mathbf{L S D}^{\mathbf{a}}$ & $\mathbf{C V}^{\mathbf{b}}$ & Significance \\
\hline Plant Height $(\mathrm{cm})$ & $32.31 \mathrm{~B}$ & $35.24 \mathrm{~A}$ & $36.11 \mathrm{~A}$ & 34.55 & 1.50 & 8.49 & ** \\
\hline Plant diameter $(\mathrm{cm})$ & $45.75 \mathrm{~B}$ & $55.67 \mathrm{~A}$ & $57.30 \mathrm{~A}$ & 52.91 & 2.19 & 8.10 & $* *$ \\
\hline Fresh herb yield (g plant $\left.{ }^{-1}\right)$ & $176.24 \mathrm{C}$ & 209.82B & $251.31 \mathrm{~A}$ & 212.46 & 6.37 & 5.85 & $* *$ \\
\hline Fresh leaves yield $\left(\mathrm{g}\right.$ plant $\left.{ }^{-1}\right)$ & $33.40 \mathrm{~B}$ & $38.97 \mathrm{~A}$ & $27.33 \mathrm{C}$ & 33.23 & 2.03 & 11.94 & ** \\
\hline Fresh flower yield $\left(\mathrm{g} \mathrm{plant}^{-1}\right)$ & & 121.94B & $158.24 \mathrm{~A}$ & 120.84 & 5.10 & 7.05 & ** \\
\hline Dry herb yield $\left(\mathrm{g} \mathrm{plant}^{-1}\right)$ & $54.52 \mathrm{C}$ & $67.43 \mathrm{~B}$ & $84.73 \mathrm{~A}$ & 68.89 & 3.24 & 9.17 & $* *$ \\
\hline Dry leaves yield $\left(\mathrm{g} \mathrm{plant}^{-1}\right)$ & $14.33 \mathrm{~B}$ & $16.72 \mathrm{~A}$ & $12.67 \mathrm{C}$ & 14.57 & 1.29 & 17.29 & ** \\
\hline Dry flowers yield $\left(\mathrm{g}_{\text {plant }}{ }^{-1}\right)$ & - & $37.71 \mathrm{~B}$ & $53.63 \mathrm{~A}$ & 45.67 & 3.11 & 13.21 & $* *$ \\
\hline Leaves essential oil rate $\left(\mathrm{ml} 100 \mathrm{~g}^{-1}\right)$ & $2.77 \mathrm{~A}$ & $2.43 \mathrm{~B}$ & $1.67 \mathrm{C}$ & 2.29 & 0.14 & 3.14 & $* *$ \\
\hline Flowers essential oil rate $\left(\mathrm{ml} 100 \mathrm{~g}^{-1}\right)$ & & $4.75 \mathrm{~A}$ & 4.60B & 4.68 & 0.12 & 1.16 & * \\
\hline Leaves essential oil yield (ml plant ${ }^{-1}$ ) & $0.40 \mathrm{~A}$ & $0.41 \mathrm{~A}$ & $0.21 \mathrm{~B}$ & 0.34 & 0.02 & 16.27 & ** \\
\hline Flowers essential oil yield (ml plant $\left.{ }^{-1}\right)$ & - & $1.79 \mathrm{~B}$ & $2.47 \mathrm{~A}$ & 2.13 & 0.14 & 13.14 & ** \\
\hline
\end{tabular}

${ }^{\mathrm{a}}$ : Least significant difference, ${ }^{\mathrm{b}}$ : Coefficient of variation, $*: \mathrm{P}<0.05$, **: $\mathrm{P}<0.01$, Levels not connected by the same letter are significantly (p < 0.05 ) different according to the Least Significant Difference test. 


\subsection{Chemical Composition of Essential Oil}

The chemical composition of essential oils for T. eigii was analyzed by GC/MS, and obtained results were summarized (Table 2). The chemical composition of essential oils varied according to growth stages and organs. Representative GC-MS chromatograms of the essential oil were given in Figure 1. Twenty-seven compounds were found, representing 94.10$98.84 \%$ of the total essential oil.

The major compounds for T. eigii were carvacrol (70.87$77.98 \%)$, p-Cymene (3.39-7.46\%), $\beta$-Caryophyllene (3.90$5.17 \%), \gamma$-Terpinene $(0.58-5.15 \%)$, Isoborneol (0.30-3.58\%), respectively. For carvacrol, the highest values were obtained from the flowers in mid-flowering and full flowering, and from leaves in pre-flowering. Compared to leaves and flowers, carvacrol was found in higher amounts in the flowers. In several previous studies, carvacrol was obtained as the main compound in the essential oils of T. eigii by the researchers; $64.61 \%$ (Baser et al., 1996), 56.71\% (Ozguven and Kirici, 2002), 43.63\% (Azaz et al., 2010). Our results were found higher than them with a mean of $74.84 \%$. However, Tepe et al. (2004) and Ulukanli et al. (2018) reported the main compound as thymol. For p-Cymene, the highest values were obtained from the leaves in fullflowering time. Similar to what we detected in this study, pCymene was found as the second-highest compound by the researchers; 7.41 (Baser et al., 1996), 13.0\% (Tepe et al., 2004). Similar to Baser et al. (1996) and Tepe et al. (2004) $\beta$ caryophyllene was determined as the third-highest compound in this study.

Compared to carvacrol content of some other plants from the Thymus genus, it was reported in T. vulgaris; $84.10 \%$ (Thompson et al., 2003), 2.80\% (Rota et al., 2008), 10.30\% (Pavela and Sedlák, 2018), 6.65-8.70\% (Gedikoglu et al., 2019) $53.67 \%$ (György et al., 2020); in T. serpyllum 4.7\% (Nikolić et al., 2014), 17.4\% (Galovičová et al., 2021); in T. pulegioides
21.23\% (Mockute and Bernotiene, 2001), \%16.83 (Vaičiulytè et al., 2017); in T. praecox 1.08\% (Ozen et al., 2011), $22.20 \%$ (Avci, 2011); in T. algeriensis 1.70\% (Dob et al., 2006), 7.76\% (Ait-Ouazzou et al., 2011), 14.00\% (Nikolić et al., 2014), in T. zygis 3.45\% (Sotomayor et al., 2004), 3.12\% (Jordán et al., 2009). Tumen et al. (1995) reported that Thymus genera grown in Turkey with high carvacrol content are T. eigii (between 3065), T. kotschyanus var. glabrescens (53\%), T. kotschyanus var. kotschyanus (60\%), T. longicaulis subsp. chaubardii var. chaubardii (42\%), T. sipthorpii (39-40\%), T. zygioides var. lycaonicus $(62 \%)$. There is higher carvacrol in T. eigii, among the Thymus spp. grown in Turkey. In the findings, it can be observed that the carvacrol content of reported some Thymus species does not reach the carvacrol content of $\mathrm{T}$. eigii. Carvacrol is a monoterpene phenol found in the essential oils of oregano and thyme (Campana and Baffone, 2018). It has stronger antibacterial properties than the other volatile compounds found in oregano and thyme essential oils (SharifiRad et al., 2018). Carvacrol's antibacterial effect involves the breakdown of the cytoplasmic membrane, which increases permeability and depolarizes potential, and various genetic and environmental variables can impact its antibacterial activity $(\mathrm{Xu}$ et al., 2008; Ait-Ouazzou et al., 2013). It is a GRAS (generally recognized as safe) chemical that can be used as a food additive in China, the United States, and the European Union (Liu et al, 2021). Moreover, Kulkarni et al. (2020) indicated that carvacrol, in particular, has great potential as a coronavirus inhibitor. Javed et al. (2021) hypothesized on the probable mechanism of a carvacrol protective effect against a COVID-19 infection, citing carvacrol's three bioactive activities as immunomodulatory, antiinflammatory, and antiviral. Evidently, the composition of essential oils is an important marker in medicinal and aromatic plants that has been influenced by a number of factors such as plant species, plant age, climatic conditions, agricultural practices, plant development stages, soil properties, post-harvest processing.

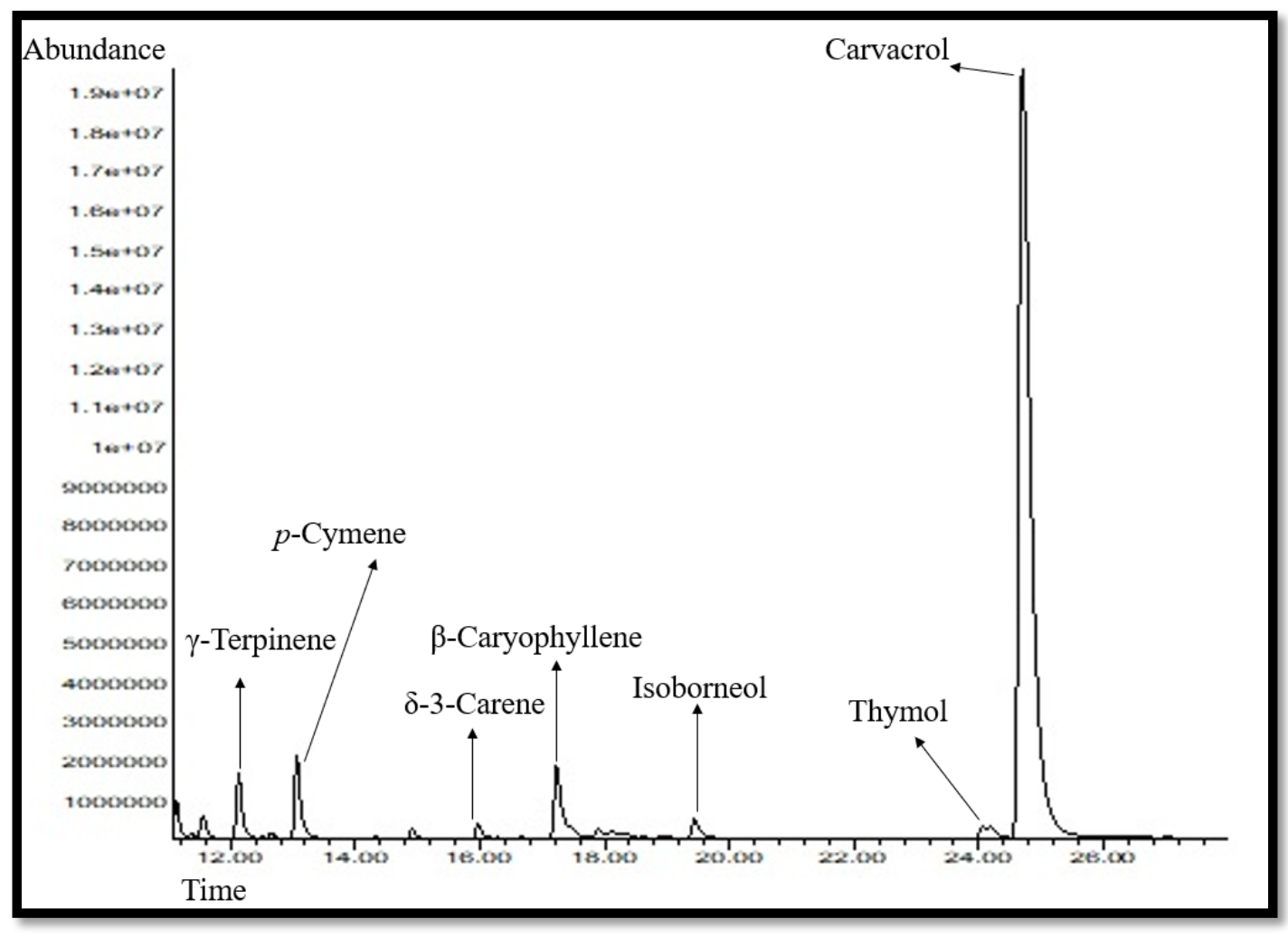

Figure 1. The representative GC/MS chromatogram of major essential oil compounds from Thymus eigii 
Table 2. Essential oil compounds of Thymus eigii from different growth stages and organs

\begin{tabular}{|c|c|c|c|c|c|c|c|}
\hline \multirow{5}{*}{ Essential Oil Compounds } & \multirow{5}{*}{ RT } & \multicolumn{5}{|c|}{ Growth Stages } & \multirow{5}{*}{ LSD (\%5) } \\
\hline & & Pre-Flowering & Mid-Flowering & Mid-Flowering & Full-Flowering & Full-Flowering & \\
\hline & & \multicolumn{5}{|c|}{ Organs } & \\
\hline & & Leaves & Leaves & Flowers & Leaves & Flowers & \\
\hline & & \multicolumn{5}{|c|}{ Relative Peak Area (\%) } & \\
\hline Myrcene & 11.134 & 0.80 & 0.57 & 1.43 & - & 1.35 & - \\
\hline Alpha-Phellandrene & 11.372 & 0.11 & - & 0.18 & 0.52 & 0.15 & - \\
\hline$\alpha$-Terpinene & 11.556 & 0.84 & 0.59 & 1.59 & - & 1.13 & - \\
\hline$\gamma$-Terpinene ${ }^{* *}$ & 12.132 & $2.14 C$ & $0.58 E$ & $5.15 \mathrm{~A}$ & $0.92 D$ & $3.11 B$ & 0.27 \\
\hline Terpinolene & 12.517 & - & 0.04 & - & 0.05 & 0.13 & - \\
\hline Eucalyptol & 12.654 & 0.10 & 0.31 & 0.30 & 0.59 & 0.36 & - \\
\hline$p$-Cymene $* *$ & 13.063 & $4.74 \mathrm{C}$ & $6.82 B$ & $3.39 \mathrm{E}$ & $7.46 \mathrm{~A}$ & 4.38D & 0.06 \\
\hline 3-Octanol & 14.909 & 0.29 & 0.28 & 0.36 & 0.37 & 0.16 & - \\
\hline 1-Octen-3-Ol & 14.915 & 1.16 & 1.01 & - & 1.30 & 0.60 & - \\
\hline$\beta$-Bourbonene & 15.526 & 0.20 & 0.40 & 0.04 & 0.28 & 0.09 & - \\
\hline$\delta$-3-Carene & 15.972 & 0.82 & 1.17 & 0.55 & 1.31 & 0.91 & - \\
\hline 3-Carene & 16.298 & 0.30 & 0.35 & 0.07 & 0.35 & - & - \\
\hline Valencene & 16.678 & 0.25 & 0.37 & 0.17 & 0.23 & 0.18 & - \\
\hline Beta-Caryophyllene** & 17.236 & $4.48 \mathrm{C}$ & $5.08 \mathrm{AB}$ & $5.17 \mathrm{~A}$ & 3.90D & 4.97B & 0.16 \\
\hline Bornyl Acetate & 17.901 & - & - & - & 0.95 & 0.70 & - \\
\hline$\delta$-Cadinene & 18.108 & - & - & 0.48 & 0.32 & 0.48 & - \\
\hline Bisabolene & 18.257 & 0.97 & 0.14 & 0.18 & 0.15 & 0.19 & - \\
\hline Aromadendrene & 18.334 & - & - & - & - & 0.25 & - \\
\hline$\alpha$-Cadinene & 18.625 & - & 0.21 & 0.12 & 0.10 & 0.12 & - \\
\hline Estragole & 18.844 & 0.62 & 0.49 & - & - & - & - \\
\hline$\delta$-2-Carene & 19.016 & - & - & 0.16 & - & 0.24 & - \\
\hline Isoborneol $* *$ & 19.444 & $1.31 \mathrm{C}$ & $3.58 \mathrm{~A}$ & $0.30 \mathrm{D}$ & 3.05B & $1.36 \mathrm{C}$ & 0.21 \\
\hline (-)-Carvone & 21.034 & - & - & 0.08 & 0.05 & 0.08 & - \\
\hline Thymoquinone & 21.420 & - & 1.24 & - & 0.90 & - & - \\
\hline Carvomenthene & 21.527 & - & - & 0.02 & - & - & - \\
\hline Thymol & 24.067 & 0.51 & - & 0.61 & 0.65 & 0.62 & - \\
\hline Carvacrol* & 24.708 & $76.75 \mathrm{~A}$ & $70.87 \mathrm{~B}$ & $77.98 \mathrm{~A}$ & 71.32B & 77.27A & 3.93 \\
\hline & Total & 96.39 & 94.10 & 98.33 & 94.77 & 98.84 & \\
\hline
\end{tabular}

$*: \mathrm{P}<0.05, * *: \mathrm{P}<0.01$, Levels not connected by the same letter are significantly $(\mathrm{p}<0.05)$ different according to the Least Significant Difference test.

\subsection{Principal component analysis (PCAbiplot) on correlations and heatmap according to essential oil compounds of Thymus eigii leaves and flowers in various growth stages}

PCAbiplot plays an important role to express a data source, where several components can best reflect the variance of the data. It allows to narrow the data and show the connections among the variables that make up the data. Through this analysis, one can clearly see the positive and negative correlations. There is a positive correlation between the lines that are in the same direction and close to each other, while there is a negative correlation between the opposite and distant lines. PCAbiplot on correlations was performed to visualize the effect of growth stages and plant organs (Figure 2). The experimental groups were separately discriminated using principal component analysis on correlations. Clear discrimination was revealed on the plotted scores, where component 1 and component 2 accounted for $92.90 \%$ of the total variance in terms of the essential oil components. The first axis and second axis explained $57.80 \%$ and $35.10 \%$ of the total variance, respectively. As seen in the figure, PCAbiplot indicates that carvacrol was positively correlated with $\gamma$-Terpinene. p-Cymene and isoborneol were negatively correlated with carvacrol.

The changes in essential oil compounds were visualized using a heat map. According to the heat map (Figure 3), the essential oil compounds were visualized based on the leaves and flowers in various growth stages. The differences can be observed clearly between growth stages and plant organs in the essential oil compounds. For instance, while the rate of carvacrol in the leaves was the highest in the pre-flowering harvest, this rate decreased as the harvests were delayed, but this situation did not show a similar trend in flowers. 


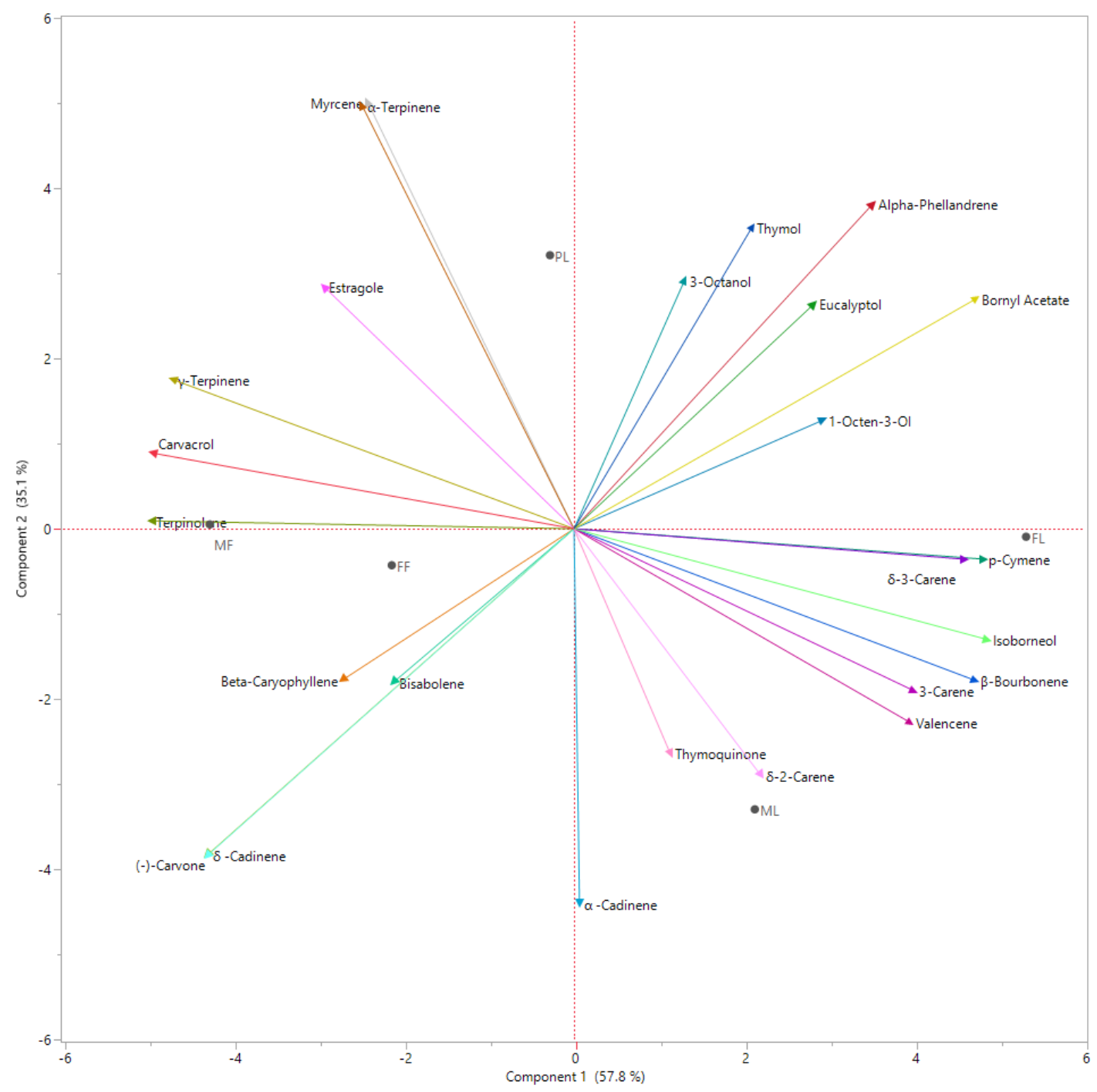

Figure 2. Principal component analysis on correlations of essential oil compounds (P: pre-flowering, M: mid-flowering, F: fullflowering; L: Leaves F: Flowers).

Value 0 80

\section{Thymoquinone}

Myrcene

a-Terpinene

Y -Terpinene

p-Cymene

1-Octen-3-OI

$\beta$-Caryophyllene

Isoborneol

Carvacrol
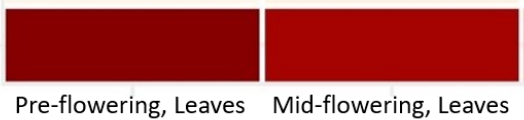

Mid-flowering, Leaves Mid-flowering, Flowers Full-flowering, Leaves

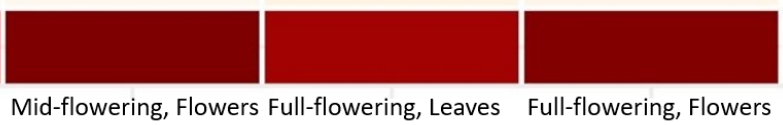

Figure 3. Heatmap based on the growth stages and plant organs for the main essential oil compounds of Thymus eigii (Value=\%). 


\section{Conclusions and Recommendations}

The active chemicals in plant organs used as drog fluctuate based on the plant's growth stages as well as variations in temperature and light during the day. Carvacrol, which is high in T. eigii, has great potential as a coronavirus inhibitor. When evaluated for the production of essential oil and carvacrol, flowers contained more carvacrol and essential oil than the leaves at mid-flowering and full-flowering. Considering its trade as a spice, pre-flowering harvest is recommended due to its high content of essential oil and carvacrol in the leaves. When considering these changes, it is important to determine which organs of the plant, at what stage of growth, and when the drug is best obtained. Thymus spp. essential oils and leaves are utilized for a variety of purposes. Therefore, among the most significant criteria to consider in cultivation are leaves and essential oil yield. It appears that cultivation of genus Thymus plants is required to provide economic profits for farmers as well as standardized quality for various purposes. It is suggested that further agronomic studies should be carried out to focus on studies to obtain higher quality products required by the market and to examine the yield and quality of Thymus eigii species in different regions.

\section{Acknowledgment}

Thanks are given to Prof. Dr. Ahmet İlçim for his helpful taxonomical identification of the plant material.

\section{References}

Ait-Ouazzou, A., Espina, L., Gelaw, T. K., de Lamo-Castellví, S., Pagán, R., \& García-Gonzalo, D. (2013). New insights in mechanisms of bacterial inactivation by carvacrol. Journal of Applied Microbiology, 114(1), 173-185.

Ait-Ouazzou, A., Lorán, S., Bakkali, M., Laglaoui, A., Rota, C., Herrera, A., ... \& Conchello, P. (2011). Chemical composition and antimicrobial activity of essential oils of Thymus algeriensis, Eucalyptus globulus and Rosmarinus officinalis from Morocco. Journal of the Science of Food and Agriculture, 91(14), 2643-2651.

Avci, A. B. (2011). Chemical variation on the essential oil of Thymus praecox ssp. scorpilii var. laniger. International Journal of Agriculture and Biology, 13(4).

Azaz, A. D., Kucukbay, Z., Çelen, S., Kuyumcu, E., \& Yildiz, B. (2010). Chemical composition, antimicrobial and antioxidant properties of Thymus eigii M. Zohary \& PH Davis essential oil. Int. J. Essent. Oil Ther, 4, 17-22.

Baser, K. H. C., Kürkçüoglu, M., Tümen, G., \& Sezik, E. (1996). Composition of the essential oil of Thymus eigii (M. Zohary et PH Davis) Jalas from Turkey. Journal of Essential Oil Research, 8(1), 85-86.

Baydar, H. (2016). Medicinal and aromatic plants science and technology book (Extended 5th Edition). Suleyman Demirel University Faculty of Agriculture, Publication No: 51. Isparta.

Campana, R., \& Baffone, W. (2018). Carvacrol efficacy in reducing microbial biofilms on stainless steel and in limiting re-growth of injured cells. Food Control, 90, 10-17.

Davis, P. H. (1982). Flora of Turkey and the East Aegean Islands; University Press: Edinburgh, Scotland, Vol. 7, pp 349- 382.

Dob, T., Dahmane, D., Benabdelkader, T., \& Chelghoum, C.
(2006). Studies on the essential oil composition and antimicrobial activity of Thymus algeriensis Boiss. et Reut. International Journal of Aromatherapy, 16(2), 95-100.

Eurostat. (2021). Retrieved 14 October 2021, from https://ec.europa.eu/eurostat

Galovičová, L., Borotová, P., Valková, V., Vukovic, N. L., Vukic, M., Terentjeva, M., ... \& Kačániová, M. (2021). Thymus serpyllum Essential Oil and Its Biological Activity as a Modern Food Preserver. Plants, 10(7), 1416.

Gedikoglu, A., Sökmen, M., \& Çivit, A. (2019). Evaluation of Thymus vulgaris and Thymbra spicata essential oils and plant extracts for chemical composition, antioxidant, and antimicrobial properties. Food science \& nutrition, 7(5), 1704-1714.

Genesys 2021. Genesys Global Portal on Plant Genetic Resources. www.genesys-pgr.org. (Accessed 05.09.2021).

György, Z., Incze, N., \& Pluhár, Z. (2020). Differentiating Thymus vulgaris chemotypes with ISSR molecular markers. Biochemical Systematics and Ecology, 92, 104118.

Javed, H., Meeran, M. F. N., Jha, N. K., \& Ojha, S. (2020). Carvacrol, a Plant Metabolite Targeting Viral Protease (Mpro) and ACE2 in Host Cells Can Be a Possible Candidate for COVID-19. Frontiers in Plant Science, 11.

Jordán, M. J., Martínez, R. M., Martínez, C., Monino, I., \& Sotomayor, J. A. (2009). Polyphenolic extract and essential oil quality of Thymus zygis ssp. gracilis shrubs cultivated under different watering levels. Industrial Crops and Products, 29(1), 145-153.

Kocabas, Y. Z., \& Karaman, S. (2001). Essential oils of Lamiaceae family from south east Mediterranean region (Turkey). Pakistan Journal of Biological Sciences, 4(10), 1221-1223.

Könemann, B. J. H. K. G. C. P. (1999). The illustrated AZ of over 10,000 garden plants and how to cultivate them. 51-53.

Kulkarni, S. A., Nagarajan, S. K., Ramesh, V., Palaniyandi, V., Selvam, S. P., \& Madhavan, T. (2020). Computational evaluation of major components from plant essential oils as potent inhibitors of SARS-CoV-2 spike protein. Journal of Molecular Structure, 1221, 128823.

Liu, F., Jin, P., Sun, Z., Du, L., Wang, D., Zhao, T., \& Doyle, M. P. (2021). Carvacrol oil inhibits biofilm formation and exopolysaccharide production of Enterobacter cloacae. Food Control, 119, 107473.

Mockute, D., \& Bernotiene, G. (2001). The $\alpha$-terpenyl acetate chemotype of essential oil of Thymus pulegioides L. Biochemical Systematics and Ecology, 29(1), 69-76.

Nikolić, M., Glamočlija, J., Ferreira, I. C., Calhelha, R. C., Fernandes, Â., Marković, T., ... \& Soković, M. (2014). Chemical composition, antimicrobial, antioxidant and antitumor activity of Thymus serpyllum L., Thymus algeriensis Boiss. and Reut and Thymus vulgaris L. essential oils. Industrial Crops and Products, 52, 183-190.

Ortiz PL, Fernandez I (1992). Microscobic Study of Honey and Apiary Pollci From the Province of Sevile. Departmento de Biologia Vegetaly, Ecologia facultad de Biologia, Apdo, 1095.41080, Sevilla Spain, Abstract.

Ozen, T., Demirtas, I., \& Aksit, H. (2011). Determination of antioxidant activities of various extracts and essential oil compositions of Thymus praecox subsp. skorpilii var. skorpilii. Food Chemistry, 124(1), 58-64.

Ozguven, M., \& Kirici, S. (2002). Domestication and Determination of Drug and Essential Oil Yield of Thymus eigii (M. Zohary et PH Davis) Jalas. In Proceedings of the 
Workshop on Agricultural and Quality Aspects of Medicinal

174-179. and Aromatic Plants (Vol. 29, pp. 255-261).

Ozguven, M., \& Sekeroglu, N. (2008). The effects of different harvesting time and drying methods on the yield and essential oil content of Thymus eigii (M. Zohary et PH Davis) Jalas. In Proceedings of the Fifth Conference on Medicinal and Aromatic Plants of Southeast European Countries,(5th CMAPSEEC), Brno, Czech Republic, 2-5 September, 2008. Mendel University of Agriculture and Forestry in Brno.

Ozguven, M., \& Tansi, S. (1998). Drug yield and essential oil of Thymus vulgaris $\mathrm{L}$. as in influenced by ecological and ontogenetical variation. Turkish Journal of Agriculture and Forestry, 22(6), 537-542.

Pavela, R., \& Sedlák, P. (2018). Post-application temperature as a factor influencing the insecticidal activity of essential oil from Thymus vulgaris. Industrial Crops and Products, 113, 46-49.

Rasooli, I., \& Mirmostafa, S. A. J. F. (2002). Antibacterial properties of Thymus pubescens and Thymus serpyllum essential oils. 73(3), 244-250.

Rota, M. C., Herrera, A., Martínez, R. M., Sotomayor, J. A., \& Jordán, M. J. (2008). Antimicrobial activity and chemical composition of Thymus vulgaris, Thymus zygis and Thymus hyemalis essential oils. Food control, 19(7), 681-687.

Ryman, D. (1992). Aromatherapy: the encyclopedia of plants and oils and how they help you: Piatkus Books.

Sharifi-Rad, M., Varoni, E. M., Iriti, M., Martorell, M., Setzer, W. N., del Mar, C. M., ... \& Sharifi-Rad, J. (2018).

Carvacrol and human health: a comprehensive review. Phyther Res 32: 1675-1687.

Sotomayor, J. A., Martínez, R. M., García, A. J., \& Jordán, M. J. (2004). Thymus zygis subsp. gracilis: watering level effect on phytomass production and essential oil quality. Journal of Agricultural and Food chemistry, 52(17), 5418-5424.

Stahl-Biskup, E. J. J. o. E. O. R. (1991). The chemical composition of Thymus oils: a review of the literature 19601989. 3(2), 61-82.

Tepe, B., Daferera, D., Sökmen, M., Polissiou, M., \& Sökmen, A. (2004). In vitro antimicrobial and antioxidant activities of the essential oils and various extracts of Thymus eigii M. Zohary et PH Davis. Journal of Agricultural and Food Chemistry, 52(5), 1132-1137.

Thompson, J. D., Chalchat, J. C., Michet, A., Linhart, Y. B., \& Ehlers, B. (2003). Qualitative and quantitative variation in monoterpene co-occurrence and composition in the essential oil of Thymus vulgaris chemotypes. Journal of Chemical Ecology, 29(4), 859-880.

TUBIVES (2021). Retrieved 14 October 2021, from http://194.27.225.161/yasin/tubives/index.php

Tumen, G., Kirimer, N., \& Baser, K. (1995). Composition of the essential oils of Thymus species growing in Turkey.

Ulukanli, Z., Cenet, M., Ince, H., \& Yilmaztekin, M. (2018). Antimicrobial and herbicidal activities of the essential oil from the Mediterranean Thymus eigii. Journal of Essential Oil Bearing Plants, 21(1), 214-222.

Vaičiulyte, V., Ložienè, K., Taraškevičius, R., \& Butkienė, R. (2017). Variation of essential oil composition of Thymus pulegioides in relation to soil chemistry. Industrial Crops and Products, 95, 422-433.

Xu, J., Zhou, F., Ji, B. P., Pei, R. S., \& Xu, N. (2008). The antibacterial mechanism of carvacrol and thymol against Escherichia coli. Letters in Applied Microbiology, 47(3), 